\title{
PATH ANALYSIS ON THE DETERMINANTS OF HYPERTENSION IN WOMEN IN SRAGEN, CENTRAL JAVA
}

\author{
Sudaryanto'), Setyo Sri Rahardjo²), Dono Indarto3) \\ 1)Masters Program in Public Health, Universitas Sebelas Maret \\ 2)Department of Pharmacology, Faculty of Medicine, Universitas Sebelas Maret \\ 3)Department of Physiology, Faculty of Medicine, Universitas Sebelas Maret
}

\begin{abstract}
Background: Hypertension is an important risk factor for cardiovascular disease in women but is often underestimated and undiagnosed. There is an ongoing misperception that women are at a lower risk of cardiovascular disease than men. The purpose of this study was to examine determinants of hypertension in women in Sragen, Central Java using path analysis model.

Subjects and Method: A case control study was carried out in Sragen, Central Java, from September 25 to November 25, 2018. A sample of 200 women was selected for this study by fixed disease sampling. The dependent variable was hypertension. The independent variables were age, BMI, history of hypertension, stress, smoking, physical activity, consumption, and cholesterol level. Data on blood pressure was measured by sphygmomanometer. The other data were collected by questionnaire. The data were analyzed by path analysis.

Results: The risk of hypertension in women was directly and positively affected by smoking $(b=3.52 ; 95 \% \mathrm{CI}=1.00$ to $6.05 ; \mathrm{p}=0.006)$, age $<20$ or $\geq 35$ years $(b=1.25 ; 95 \%$ $\mathrm{CI}=0.30$ to $2.20 ; \mathrm{p}=0.010)$, high stress $(\mathrm{b}=1.79 ; 95 \% \mathrm{CI}=0.63$ to $2.96 ; \mathrm{p}=0.003)$, high salt consumption $(b=2.49 ; 95 \% \mathrm{CI}=0.25$ to $4.73 ; \mathrm{p}=0.029)$, high cholesterol level $(b=1.78 ; 95 \% \mathrm{CI}=0.68$ to $2.89 ; \mathrm{p}=0.001)$, history of hypertension $(\mathrm{b}=1.41 ; 95 \%$ $\mathrm{CI}=0.33$ to $2.50 ; \mathrm{p}=0.010)$, and $\mathrm{BMI} \geq 25(\mathrm{~b}=1.14 ; 95 \% \mathrm{CI}=0.17$ to $2.11 ; \mathrm{p}=0.020)$. The risk of hypertension was directly and negatively affected by high physical activity $(\mathrm{b}=-$ 2.00; $95 \% \mathrm{CI}=-3.09$ to $-0.92 ; \mathrm{p}<0.001$ ). It was indirectly affected by physical activity and stress.
\end{abstract}

Conclusion: The risk of hypertension in women is directly and positively affected by smoking, age, stress, salt consumption, high cholesterol level, history of hypertension, and BMI $\geq 25$. The risk of hypertension in women decreases with high physical activity. It is indirectly affected by physical activity and stress.

Keywords: hypertension, determinants, women, path analysis

\section{Correspondence:}

sudaryanto. Masters Program in Public Health, Universitas Sebelas Maret, Jl. Ir. Sutami 36 A, Surakarta 57126, Central Java. Email: oment8147@gmail.com.

Mobile: +6285727565551.

The $5^{\text {th }}$ International Conference on Public Health Best Western Premier Hotel, Solo, Indonesia, February 13-14, 2019 | 63 https://doi.org/10.26911/theicph.2019.01.09 